\title{
ЗАХИСТ ЕКОЛОГІЧНИХ ПРАВ ЛЮДИНИ В ЄВРОПЕЙСЬКОМУ СУДІ З ПРАВ ЛЮДИНИ
}

Лихогляд В. П.

У статmі аналізуються основні підходи до екологічних прав людини та механізми їх захисту в Європейському суді з прав людини. Гнучке тлумачення Європейської конвенції про захист прав людини і основоположних свобод (далі Європейська конвенція, Конвенція або ЄКПЛ), дозволяє Європейському суду постійно визначати оновлені підходи до захисту екологічних прав. Аналізується підхід Європейського суду до вирішення проблеми захисту екологічних прав людини: він має здійснюватися на національному рівні, зокрема шляхом вдосконалення національного законодавства, використання практики Європейського суду як джерела права національними судами, що дозволить попередити порушення екологічних прав людини. Окрема увага приділяється практиці Європейського суду щодо можливостей захисту екологічних прав, навіть тоді, коли вони не закріплені в Європейській конвенції про захист прав людини і основоположних свобод 1950 року.

Ключові слова: соціальна відповідальність, захист прав людини, міжнародне право, позитивні зобов'язання держави, доступ до інформації, Європейський суд з прав людини.

В статье анализируются основные подходы к экологическим правам человека и механизмы их защиты в Европейском суде по правам человека. Гибкое толкование Европейской конвенции о защите прав человека и основных свобод (далее - Европейская конвенция, Конвенция или ЕКПЧ) позволяет Европейскому суду постоянно определять обновленные подходы к защите экологических прав. Анализируется подход Европейского суда к решению проблемы защиты экологических прав человека: такая защита должна осуществляться на национальном уровне, в частности путем совершенствования национального законодательства, использования практики Европейского суда как источника права национальными судами, что позволит предупредить нарушения экологических прав человека. Особое внимание уделяется практике Европейского суда относительно возможностей защиты экологических прав, даже если они не закреплены в Европейской конвенции о защите прав человека и основных свобод 1950 года.

Ключевые слова: социальная ответственность, защита прав человека, международное право, позитивные обязательства государства, доступ к информации, Европейский суд по правам человека.

This article analyzes the main approaches to environmental human rights and the mechanisms for their protection at the European Court of Human Rights. The flexible interpretation of the European Convention for the Protection of Human Rights and Fundamental Freedoms (hereinafter European Convention, Convention or ECHR) allows the European Court of Human Rights to constantly identify updated approaches to the protection of environmental rights. It analyzes the approach of the European Court of Human Rights to address the issue of protecting environmental human rights: such protection should be exercised at national level, in particular by improving national law, using the case law of the European Court of Human Rights as a source of law by national courts, which, in turn, will prevent the violation of environmental human rights.
The Court has increasingly examined complaints in which individuals have argued that a breach of one of their Convention rights has resulted from adverse environmental factors. Environmental factors may affect individual Convention rights in different ways. First, the human rights protected by the Convention may be directly affected by adverse environmental factors. Second, adverse environmental factors may give rise to certain procedural rights for the individual concerned. The Court has established that public authorities must observe certain requirements as regards information and communication, as well as participation in decision-making processes and access to justice in environmental cases. Third, the protection of the environment may also be a legitimate aim justifying interference with certain individual human rights. Particular attention is paid to the case-law of the European Court of Justice on the possibility of protecting environmental rights, even when not enshrined in the 1950 European Convention on Human Rights and Fundamental Freedoms.

Key words: social responsibility, protection of human rights, international law, positive obligations of the state, access to information, European Court of Human Rights.

Постановка проблеми та їі актуальність. Навколишнє середовище знаходиться під захистом як національного, так і міжнародного права. Європейська конвенція про захист прав людини та основоположних свобод (далі - ЄКПЛ, Конвенція) не містить положення, яке гарантує право на чисте довкілля [11]. Однак кількість справ, пов'язаних зі шкодою, що завдається людині діями/бездіяльністю влади в цій галузі, які розглядаються Європейським судом з прав людини (далі ЄСПЛ), постійно зростає.

Аналіз останніх досліджень і публікацій. На доктринальному рівні окремі аспекти захисту екологічних прав людини в Європейському суді з прав людини досліджували такі вчені як М. Коскенніємі, М. Фіцмоpic, Дж. Маршалл, Ю. Кербрат, І. Крстіч, Б. Чучковіч, І. Ценевська, Р. Десганьє, Е. Фолксон, С. Кравченко, Дж. Боніне, Ж.-Ф. Аканджі-Комба, У. Кілкеллі, Б. Кларк, М. Клемсон та інші.

Мета статті полягає в аналізі механізмів і тенденцій розгляду справ, пов'язаних з екологічними правами людини в Європейському суді з прав людини.

Виклад основного матеріалу. 3 метою захисту екологічних прав людини відповідно до Конвенції зазвичай застосовуються права, які вже закріплені в ЄКПЛ i, на перший погляд, не мають відношення до екології. Розширюючи обсяг правовідносин, на які розповсюджуються гарантії Конвенції, суд застосовує джерела екологічного права. Так, у справі Di Sarno and others vs Italy (рішення ЄСПЛ від 10 січня 2012 року) суд зіслався на положення Конвенції ООН про доступ до інформації, участь громадськості в процесі прийняття рішень 
і доступ до правосуддя з питань, які стосуються навколишнього середовища (Орхуська конвенція 1998 року), розширивши область зобов'язання з надання інформації про загрози і включивши туди не тільки небезпечну діяльність людини, а й стихійні лиха [5]. Суд зіслався на цей договір як на джерело міжнародного права в сфері охорони здоров'я і в справі Tașkin and others vs. Turkey (рішення ЄСПЛ від 10 листопада 2004 року), незважаючи на те, що Туреччина не $\epsilon$ учасницею цієї угоди.

Екологічні фактори можуть зачіпати права людини, гарантовані Конвенцією, по-різному. Наприклад, у низці справ ЄСПЛ встановив обов'язок влади дотримуватися певнихвимогуцарині надання інформації, участі зацікавлених осіб у процесі прийняття рішень, а також доступу до правосуддя в справах, пов'язаних з екологічними ризиками. Крім того, захист навколишнього середовища може бути законною підставою обмеження низки прав людини, наприклад права на користування майном [9].

Європейський суд з прав людини розглядав справи, які зачіпають питання захисту навколишнього середовища, в рамках декількох статей Конвенції:

1) ст. 2 (право на життя) в контексті небезпечної промислової діяльності, впливу радіації, впливу промислових викидів на здоров'я, природних катастроф;

2) ст. 3 (свобода від катувань, нелюдського та такого, що принижує гідність, поводження) в контексті пасивного куріння в місцях позбавлення волі;

3) ст. 6 (право на справедливий суд) в контексті доступу до суду і на виконання остаточного рішення суду;

4) ст. 8 (право на повагу до приватного, сімейного життя, захисту кореспонденції і житла) в контексті доступу до інформації про екологічні ризики, промислового забруднення навколишнього середовища, впливу шуму на людину, міського розвитку, збору і переробки відходів тощо;

5) Ст. 10 (право на отримання і поширення інформації) в контексті вчинення процесуальних дій, необхідних для захисту своїх законних інтересів;

6) ст. 11 (свобода зібрань та об'єднань) у контексті реалізації права на захист прав людини і протест;

7) ст. 1 протоколу 1 до ЄКПЛ (захист власності) в контексті відкликання дозволу на будівництво.

При цьому саме ст. 8 безпосередньо пов'язана із захистом людини від негативного впливу навколишнього середовища, а прогресивна практика ЄСПЛ із цих питань розглядається деякими вченими [1]. Ця стаття присвячена висвітленню цієї практики і принципам, які було вироблено судом при розгляді подібних справ.

Погіршення стану навколишнього середовища. Ключовим принципом практики ЄСПЛ у справах, пов'язаних із впливом екологічних факторів на людину, $\epsilon$ положення про те, що погіршення стану навколишнього середовища саме по собі не обов'язково тягне за собою визнання порушення ст. 8 ЄКПЛ. Суд продовжує повторювати в своїх рішеннях, що ЄКПЛ не закріплює права на захист навколишнього середовища або збереження природи. Так, у справі Kyrtatos vs Greece (рішення ЄСПЛ від 22 травня 2003 року), яка стосувалася незаконного осушення болотистої місцевості, ЄСПЛ розділив скарги заявників на дві частини. Перша стосувалася міського розвитку, який призвів до зникнення болота, що знаходилося неподалік від заявників, через що їх перестала оточувати мальовнича природа. Друга частина скарги полягала в тому, що забруднення навколишнього середовища (шуми і нічні вогні будівництва) порушили їх права, гарантовані ст. 8.

Щодо першої частини скарги ЄСПЛ заявив, що ні ст. 8, ні жодна інша стаття ЄКПЛ не передбачають загальне право на захист навколишнього середовища як такого. Для цього будуть більш доречними інші міжнародні інструменти, а також внутрішнє законодавство. Суд зазначив, що навіть якщо припустити, що міське будівництво значним чином змінило екологію в цьому районі, залишається недоведеним, що збиток, нанесений птахам та іншим охоронюваним видам, які жили на болоті, торкнувся права заявників за ст. 8 ЄКПЛ. Таким чином, втручання в екосистему болота не призвело до порушення права заявників на приватне життя. Щодо другої частини скарги ЄСПЛ заявив, що занепокоєння, яке відчували заявники від прилеглої забудови, не досягло рівня значущості, необхідного для застосування ст. 8 ЄКПЛ.

Аргумент про те, що захист навколишнього середовища і прав людини не обов'язково $€$ перешкодою міському розвитку, суд повторив кілька місяців по тому в справі Hatton and others vs UK (рішення ЄСПЛ від 8 липня 2003 року), в якій заявники стверджували, що політика влади Сполученого Королівства стосовно нічних польотів в аеропорту «Хітроу» порушувала їх права, гарантовані ст. 8 [7]. У цій справі ЄСПЛ проаналізував точки зору сторін стосовно меж розсуду держави. 3 одного боку, влада Великобританії заявляла про широке трактування розсуду з огляду на те, що справа стосувалася питань загальної політики; з іншого боку, заявники стверджували, що йшлося про вплив нічних польотів на сон, а межі розсуду звузилися внаслідок «інтимного» характеру охоронюваного права.

Ухвалюючи рішення, ЄСПЛ повністю поклався на те, що «національна влада знаходиться в кращому положенні по відношенню до міжнародних судів, щоб оцінювати місцеві потреби і умови», і не встановив порушення ст. 8 ЄКПЛ. Прийнятий ЄСПЛ підхід свідчить про те, що знаходити баланс між різними інтересами в справах, пов'язаних із захистом екології, повинні національні або міжнародні політичні інстанції, а не суди з прав людини. Така позиція не дуже перспективна з точки зору захисту навколишнього середовища в контексті прав людини.

Застосування правила “de minimus”. Ще один принцип, вироблений ЄСПЛ, - необхідність досягнення певного рівня серйозності впливу екологічних факторів на людину. Встановлюючи це правило (правило “de minimus"), ЄСПЛ вважає, що слід розглянути два питання: про наявність причинно-наслідкового зв'язку між діяльністю і негативним впливом і про те, чи сягнув цей вплив критичного рівня. У справі Fadeyeva vs Russia (рішення ЄСПЛ від 9 червня 2005 року) заявниця стверджувала, що господарська діяльність металургійного підприємства в безпосередній близькості від ії будинку піддавала небезпеці іï здоров'я і благополуччя.

ЄСПЛ зазначив, що оцінка впливу на здоров'я «відносна і залежить від усіх обставин справи, наприклад від інтенсивності і тривалості правопорушення, його матеріальних або психічних результатів. Необхідно також взяти до уваги загальний екологічний контекст. Якщо оскаржуване правопорушення мало незначний вплив порівняно з екологічними небезпеками, властивими життю в будь-якому сучасному місті, для застосування ст. 8 немає підстав» (\$69 рішення). 


\section{Проблеми \\ екологічного законодавства}

Аналізуючи втручання в життя заявниці, суд встановив, що «навіть якщо допустити, що забруднення не нанесло якоїсь вимірюваної шкоди ії здоров'ю, воно неминуче зробило заявницю більш вразливою до різних захворювань. Крім того, немає жодних сумнівів у тому, що воно несприятливо позначилося на якості життя в будинку» [8]. Тому суд дійшов висновку, що фактичний збиток здоров'ю та добробуту заявниці досяг рівня, достатнього для його розгляду в рамках ст. 8 Конвенції (§88). ЄСПЛ визнав порушення Конвенції в цій справі. Однак він знову підкреслив широкі межі розсуду влади і субсидіарність своєї ролі, яка зводиться до встановлення «явної помилки влади» щодо визначення балансу між конкуруючими інтересами і дистанціювався таким чином від екологічної тематики [8, §105].

Позитивні зобов'язання держав. Ст. 8 ЄКПЛ передбачає захист приватної особи від втручання влади в її приватне та сімейне життя, житло і кореспонденцію. При цьому вона може передбачати і обов'язок здійснити певні позитивні заходи для забезпечення гарантованих прав. Так, у справі Dzemyuk vs Ukraine (рішення ЄСПЛ від 4 вересня 2014 року) заявник стверджував, що його права порушені тим, що неподалік від його будинку було побудовано кладовище, у зв'язку з чим ґрунтові води стали непридатними для поливу і споживання в їжу. Йшлося, зокрема, про те, що діяльність місцевої влади не відповідала наявним екологічним стандартам.

ЄСПЛ підкреслив, що в такій ситуації до його завдання входить оцінка того, чи вжила влада всіх розумних заходів для забезпечення захисту прав заявника за ст. 8 Конвенції. При цьому він повинен був оцінити такі фактори як відповідність національному законодавству в сфері захисту навколишнього середовища і виконання судових рішень. Європейський суд з прав людини зазначив, що якщо на національному рівні існує екологічне законодавство, порушення ст. 8 може бути встановлено у зв'язку з порушенням цього законодавства (§ 88-89 рішення).

Суд вказав, що принципи, які застосовуються до оцінки обов'язків держави в екологічних справах, загалом схожі, незалежно від того, в якому контексті розглядається справа - в плані позитивних зобов'язань або в плані «втручання органів державної влади», яке повинно бути виправдане з точки зору ч. 2 ст. 8. Наявні процедурні гарантії можуть бути визнані неефективними, а держава - винною в порушенні Конвенції в разі, якщо рішення суду, що пропонує зробити певні дії, було проігноровано владою або залишалося невиконаним протягом значного проміжку часу. Позитивні зобов' язання покладаються на владу не тільки у випадках, коли шкода завдана безпосередньо державою, але і коли вона була заподіяна діяльністю підприємств, що знаходяться в приватній власності [4].

У справі Di Sarno and others vs Italy (рішення ЄСПЛ від 10 січня 2012 року) суд зазначив, що в контексті небезпечних видів діяльності на держави покладаються зобов'язання їх регулювати, враховуючи, зокрема, рівень потенційного ризику. Підлягає регулюванню ліцензування, операційна діяльність, безпека і нагляд за такою діяльністю. Крім того, держави повинні зобов'язати тих, хто здійснює таку діяльність, робити практичні кроки щодо забезпечення безпеки громадян, чиї життя можуть бути піддані ризику (\$106 рішення).
Суд встановив, що прямого втручання влади у права заявників не було. Проте не було вжито й заходів, необхідних для забезпечення належного збору, переробки та знищення сміття в одній із муніципальних областей. Оскільки ця діяльність $€$ небезпечною, на владі «лежало позитивне зобов'язання вжити заходів для того, щоб убезпечити житло і приватне життя людей, а також їх право жити в безпечному і здоровому довкіллі. Той факт, що італійська влада передоручила управління цим процесом третім особам, не звільняє ії від цього зобов'язання» [5, §110].

У справі Ledyayeva and others vs Russia (рішення ЄСПЛ від 6 жовтня 2006 року), аналогічній справі Fadeyeva vs Russia, розглянутій вище, суд зазначив, що влада не надала жодних нових аргументів, які привели б суд до інших висновків, ніж ті, що були зроблені ним у справі Fadeyeva vs Russia [8]. Отже, вони залишаються незмінними - влада не вжила заходів, необхідних для захисту права заявників на повагу до їх житла і приватного життя від значного негативного екологічного впливу. Зокрема, не було розроблено і не було застосовано дієві заходи для того, щоб примусити керівництво металургійного комбінату скоротити викиди до прийнятного рівня в розумні строки, чим були порушені права заявників, передбачені ст. 8 (\$110 рішення).

ЄСПЛ підтвердив, що позитивні обов'язки держави в ситуаціях, пов'язаних з екологічними факторами, можуть виникати з нездатності регулювати приватний сектор промисловості [5, с. 53]. У справі Dubetska and others vs Ukraine (рішення ЄСПЛ від 10 лютого 2011 року) ЄСПЛ застосував той самий принцип у ситуації, коли підприємство, яке раніше належало державі, було приватизовано. Для визначення того, чи несе влада відповідальність за шкоду, заподіяну заявникам, суд звернув увагу на те, «чи була ця ситуація результатом раптового і несподіваного повороту подій або навпаки вона тривала вже довго, і органи державної влади були добре з нею знайомі; чи були державні органи повідомлені або повинні були бути повідомлені про те, що небезпека або шкідливий викиди вплинули на особисте життя заявника, а також наскільки заявниця сама сприяла створенню ситуації, в якій вона опинилася, чи була вона в змозі усунути таку ситуацію дозволеними засобами» [3, §108].

Межі розсуду держави. У ситуаціях, коли дії влади впливають на екологію настільки значно, що це призводить до втручання у право на повагу до приватного, сімейного життя або житла, ці дії повинні відповідати вимогам ч. 2 ст. 8 ЄКПЛ. Вони повинні бути передбачені законом, переслідувати законні цілі і бути пропорційними до переслідуваної мети. Для забезпечення пропорційності необхідне досягнення балансу між інтересами приватних осіб і інтересами суспільства. Суд неодноразово зазначав, що соціальні та технічні аспекти питань, пов'язаних із навколишнім середовищем, часто складно виміряти і оцінити. У зв'язку з цим була вироблена однозначна позиція, згідно з якою саме національні органи влади мають у своєму розпорядженні всі можливості для того, щоб оцінити ці аспекти, мають широкі межі розсуду. При цьому суд може вирішити, що необхідно оцінити, чи сумлінно діяла влада при розгляді ситуації, яка склалася, чи взяла вона до уваги всі конкуруючі інтереси, як це підкреслюється в «Керівництві з прав людини і навколишнього середовища» [5, с. 55]. 
У справі Dubetska and others vs Ukraine суд встановив, що хоча «вирішення екологічних проблем, пов'язаних із роботою двох великих промислових підприємств, які функціонували з порушенням норм із самого початку і нагромаджували відходи протягом більш як 50 років, було складним завданням, яке вимагає часу і значних ресурсів, уряд не надав достатніх пояснень того, чому йому не вдалося протягом більш ніж 12 років або переселити заявників (невелику групу людей), або знайти якісь інші ефективні рішення ї індивідуального тягаря» [3, §155].

Оскільки «Конвенція спрямована на захист реальних, а не ілюзорних прав, справедливий баланс між різними протилежними інтересами сторін може бути порушений не тільки там, де недостатнє законодавство для захисту гарантованих прав, але також i там, де таке законодавство належним чином не виконується. Доступні заявнику процедурні гарантії можуть виявитися неефективними, і держава може бути визнана відповідальною за порушення прав, гарантованих Конвенцією, якщо процедури прийняття рішень $\epsilon$ невиправдано тривалими або якщо прийняте в результаті таких процедур рішення залишається невиконаним протягом тривалого часу» [3, §144]. Такий самий підхід був застосований і в справі Di Sarno and others vs Italy. ЄСПЛ зазначив, що, «незважаючи на широку сферу розсуду держави, неможливо заперечувати, що нездатність італійської влади забезпечити належне функціонування збору, переробки та знищення сміття негативно вплинула на права заявників і призвела до порушення ст. 8 Конвенції» [5, §112].

Доступ до інформації про екологічні ризики. Порушення ст. 8 ЄКПЛ у зв'язку з ненаданням інформації про загрози екологічного характеру ЄСПЛ встановлює, починаючи зі справи Guerra and Others vs Italy (рішення ЄСПЛ від 6 жовтня 2006 року), що стосувалася здоров'я осіб, які проживали неподалік від фабрики з виробництва добрив. У ній суд встановив, що влада не виконала своїх зобов'язань, оскільки протягом багатьох років не надавала заявникам інформацію, яка дозволила б їм оцінити серйозність ризику при проживанні в безпосередній близькості від підприємства, що знаходиться в аварійному стані [6].

Натепер право на доступ до інформації про потенційні або реальні екологічні ризики виділяється як одне $з$ основних процедурних прав у рамках позитивних зобов'язань в екологічних справах. Надання цьому праву такої ваги демонструє факт запозичення судом принципу перестороги (precautionary principle) з міжнародного екологічного права, вважають І. Крстич i Б. Чучковіч [10]. Цей принцип вимагає, щоб держави не відкладали прийняття заходів щодо попередження настання негативних наслідків лише через відсутність впевненості в їх настанні.

Під впливом міжнародних стандартів суд встановив, що при настанні негативних наслідків влада не може посилатися на необізнаність про небезпеку. Так, у справі Brincat and others vs Malta (рішення ЄСПЛ від 24 липня 2014 року), яка стосувалася колишніх працівників судноремонтної верфі, що працювали з азбестом, суд зауважив, що влада вважала, що забезпечення робітників інформацією не було іï обов'язком, i що робітники повинні були знати про можливі ризики. Суд вирішив, що ця позиція знаходиться в явному проти- річчі з багаторазово використаним державою аргументом, що влада протягом довгого часу не була обізнана про небезпеку. Аргумент про те, що видача масок для роботи з азбестом була непрямим джерелом інформації, з якого робітники повинні були усвідомити ступінь небезпеки, він вважав неприйнятним [2, \$114].

ЄСПЛ ще раз повторив у цій справі вироблені ним раніше позиції про доступ до інформації. Зокрема, він зазначив, що до позитивних обов'язків держави входить забезпечення доступу до важливої інформації, що сприяє особам в оцінці ступеня небезпеки для іхнього здоров'я і життя, а також, що в деяких випадках надання інформації може бути обов'язком держави (\$102). Суд не тільки підтвердив, що інформація про ті фактори, що чинять вплив на людину, повинні бути недвозначними, але й установив обов'язок держави забезпечити доступні і ефективні процедури отримання такої інформації, збільшивши обсяг права на доступ до інформації. Тепер відмова в доступі до інформаціі може стати порушенням ЄКПЛ також і в ситуаціях, коли особі ця інформація потрібна не для того, щоб реалізувати своє громадянське право.

Розвиток процедурних гарантій ст. 8 ЄКПЛ як у плані доступу до інформації, так і загалом $є$ важливим з точки зору захисту екологічних прав людини. Кількість справ із цієї тематики зростає, ЄСПЛ покладає на держави все більший обсяг зобов'язань. Це, а також готовність суду сприймати розвиток міжнародних стандартів у галузі охорони навколишнього середовища і посилатися на них, дає підставу говорити про те, що з часом суд може відійти від процедурного підходу до захисту екологічних прав і заговорити про право людини на сприятливе навколишнє середовище [1].

Висновки. На думку автора, в ЄСПЛ сформувалася чітка позиція щодо питання про роль держави в сфері охорони навколишнього середовища: ця сфера $\epsilon$ цінністю в очах суспільства, їі захист становить постійний і довготривалий інтерес з його боку. Економічні потреби і навіть деякі фундаментальні права, як наприклад право власності, не повинні превалювати над заходами щодо захисту навколишнього середовища, які в свою чергу $\epsilon$ сферою законодавчого регулювання.

Практика суду показує, що кількість справ, пов'язаних із порушеннями в сфері охорони навколишнього середовища, поступово збільшується. Можна спрогнозувати, що й надалі за відсутності ефективних заходів на національному рівні щодо забезпечення сприятливих умов навколишнього середовища кількість таких справ зростатиме. Загалом ЄСПЛ розглядає саме державу як суб'єкта, безпосередньо зобов'язаного забезпечувати нормативно-правове регулювання захисту екологічних прав людини. Отже, для ухвалення дієвого законодавства в сфері захисту екологічних прав людини держави повинні звертати увагу на практику ЄСПЛ у цій сфері.

\section{Література}

1. Cenevska I.A thundering silence: Environmental rights in the dialogue between the EU Court of justice and the European court of human rights // Journal of environmental law. Oxford, 2016. Vol. 28, № 2. P. 301-324.

2. Case of Brincat and Others v. Malta. Judgement of the European Court of human rights of 8 July 2014. URL: https://hudoc.echr.coe.int/eng\#\{\%22itemid\%22:[\%22001-145790\%22]\}. 
3. Case of Dubetska and Others v. Ukraine. Judgement of the European Court of human rights of 18 January 2011. URL: http://hudoc.echr.coe.int/sites/eng/pages/search. aspx?i=001-103273.

4. Case of Dzemyuk v. Ukraine. Judgement of the European Court of human rights of 10 May 2011. URL: https: / / hudoc.echr.coe.int / fre\#\{\%22itemid\%22: [\%22001-146357\%22]\}.

5. Case of di Sarno and Others v. Italy. Judgement of the European Court of human rights of 29 November 2011. URL: https://hudoc.echr.coe.int/eng\#\{\%22itemid\%22:[\%22001-108480\%22]\}.

6. Case of Guerra and others v. Italy. Judgement of the European Court of human rights of 19 February 1998. URL: http://hudoc.echr.coe.int/sites/eng/pages/search. aspx?i=001-58135.

7. Case of Hatton and Others v. The United Kingdom. Judgement of the European Court of human rights of 08 July 2003. URL: http://hudoc.echr.coe.int/sites/eng/pages/ search.aspx?i=001-59686.

8. Case of Fadeyeva v. Russia. Judgement of the European Court of human rights of 30 November 2005. URL: http: / / hudoc.echr.coe.int/sites/eng/pages/search. aspx?i=001-69315.

9. Case of Tașkın and Others v. Turkey. Judgement of the European Court of human rights of 10 November 2004. URL: $\quad$ https://hudoc.echr.coe.int/eng\#\{\%22itemid\%22: [\%22001-67401\%22]\}.

10. Krstić I., Čučković B. Procedural aspects of article 8 of the ECHR in environmental cases - the greening of human rights law // Anali. Beogradu, 2015. Vol. 63, № 3. URL: http://ojs.ius.bg.ac.rs/index.php/anali/article/view/152/338.

11. Європейська конвенція про захист прав людини і основоположних свобод 1950 року. URL: http://zakon4. rada.gov.ua/laws/show/995_004.

12. Протокол № 9 до Європейської конвенції від 6 листопада 1990 року. URL: http://zakon4.rada.gov.ua/ laws/show/994_170.

Лихогляд В. П., аспірантка кафедри міжнародного права Iнституту міжнародних відносин Київського національного університету імені Тараса Шевченка 